\title{
Analysis of Management Warranty Processes: A Case Study in the PT. XYZ Dealer Network
}

\author{
Moh. Nurcahyo $\mathrm{H}$ \\ Magister of Acoounting, Faculty of Economics and Business \\ University of Indonesia Jakarta, \\ Indonesia \\ cahyo.hadiwasono@gmail.com
}

\begin{abstract}
The purpose of this study is to analyze the process of and find solutions to the gaps in transit account warranty transactions in the PT. XYZ dealer network and provide proposed improvements to warranty transaction procedures. This research used qualitative methods with a case study approach and acquired data from spare parts procurement, warranty claim records, and the claim and delivery warranty process as well as the responses to warranty claims. The result showed that the weakness of the warranty process in the PT. XYZ dealer network centers on the internal control management in each of those dealers. The research suggests improving the standard operating procedures in each step of the warranty process, in particular those categories from which we procured data.
\end{abstract}

Keywords-warranty, internal control, transitory accounts, procedures analysis, standard operating procedures

\section{INTRODUCTION}

There is an increasing trend in the development of the automotive industry in recent years. Wholesales in 2017 are recorded at 1,079,534 units, up $1.6 \%$ compared to 2016 , which was $1,062,716$ units [6]. The increased sales in the Indonesian automotive industry are indirectly affected by infrastructure projects that are being encouraged by the government [12]. It is estimated that this trend will continue to increase in line with the stable economic conditions, the decrease in interest rates, and the increase in public purchasing power [6].

As the automotive industry grows, a growth characterized by an increasing volume of sales transactions, this will increase the risk facing by automotive industry players. One of the risks faced is the higher complexity of internal corporate activity, which, if not managed effectively, will result in irrelevancy in the preparation of financial statements due to erroneous in inputting journal or less control for checking the correctness of financial statement. (Murtin, 2015).

Due to the increasing volume of sales transactions, PT. $\mathrm{XYZ}$ and its dealer network, as one of the actors in the automotive industry, was also facing control management problems. PT. XYZ is a leader for the premium automobile market segment in Indonesia; for 2017 fiscal year, PT. XYZ controlled $45 \%$ of the premium segment [6]. Based on bookkeeping records at the PT. XYZ dealers' network, in 2017, retail sales at all dealerships increased by $23 \%$ compared to $2016-3,355$ units in 2017 up from 2,723 units in 2016 [4]. The total turnover in 2017 recorded was. 4,782 billion rupiah, up $26 \%$ compared to 2016 , which was recorded as 3,797 billion rupiah [4]. In the latest 5-year data from 2013 to 2017, the retail sales trend is also increasing [4].

This growing business leads to problems on the control side, one of which is warranty bookkeeping. Unreliable bookkeeping data from some warranty dealers can be seen on warranty transit accounts, which should have 0 in value but instead often fluctuate. Taken from the Dealer Management System (DMS) financial data over the past 5 years, the value of warranty-related accounts always exists and has great value, as can be seen in Table I, where the total transit warranty account value highly fluctuated from year to year. In 2013, the value reached negative 36.57 billion rupiah, rising in 2014 to positive 3.2 billion rupiah and, then, increasing sharply in 2015 and 2016 to approximately positive 49.3 billion rupiah and 49.0 billion rupiah respectively. In 2017, the number decreases again to positive 39.5 billion rupiah.

Another issue related to warranty is the procurement process for spare parts, where the transit account associated with the procurement of spare parts are booked under account named good in suspense A and good in suspense B. Since the incoming spare parts stock is not in the same day with the invoice, then these two transit account were used to book incoming spare parts stock or good receipt and the invoice register. When the stock were coming, the goods receipt process will accrue journal stock spare parts in debit side and credit good in suspense A, and by end of the month when invoice is coming, process of invoice register will create journal good in suspense B in debit side and credit the payables. Further steps is to verify good in suspense and invoice register, the purpose is to check whether amount and items reflected in invoice are same with actual incoming stock spare parts. This process will have resulted journal where good in suspense B in debit side and credit good in suspense A. The result of this process are these two accounts will have 0 balance by the end of the month, but in this case is never 0 , indicating that there is a process that is not executed or that is missed as a result of poor bookkeeping. Noted, the value of transit accounts through December 2017 is 12.2 billion rupiah 
Table I. Total Transaction Value of Transit Warranty Dealer Accounts From PT. XYZ 2013-2017

\begin{tabular}{|c|c|c|c|c|}
\hline \multicolumn{5}{|c|}{ Year } \\
\hline $\mathbf{2 0 1 3}$ & $\mathbf{2 0 1 4}$ & $\mathbf{2 0 1 5}$ & $\mathbf{2 0 1 6}$ & 2017 \\
\hline$(36,573,964,552)$ & $3,180,157,436$ & $49,257,816,548$ & $49,044,936,448$ & $39,532,171,043$ \\
\hline
\end{tabular}

table II. Procurement Transit Revenue for Spare Part Per Dealer

\begin{tabular}{|c|c|c|c|c|}
\hline \multicolumn{5}{|c|}{ Year } \\
\hline 2013 & 2014 & 2015 & 2016 & 2017 \\
\hline$(18,870,893,657)$ & $\begin{array}{l}27,498,124, \\
226\end{array}$ & $12,745,424,780$ & $123,138,910,239$ & $12,181,821.155$ \\
\hline
\end{tabular}

Another problem faced by the dealer is the number of rejected warranty claims. Most rejected claims are related to administrative matters such as errors in determining damage code, determining work hours, filing jobs not in the list, etc. Throughout 2017, warranty claim rejected due to administrative matters amounted to 2,930 of 13,110 total claims with a total value of 38.3 billion rupiah, and the rejected warranty value was 8.4 Billion rupiah [17]. The following table shows more details:

TABLE III. Total And Rejected Warranty Claims Through 2017

\begin{tabular}{|l|l|l|l|}
\hline $\begin{array}{c}\text { Total of Warranty } \\
\text { Claim }\end{array}$ & $\begin{array}{c}\text { Warranty Value } \\
\text { (In Million } \\
\text { rupiah) }\end{array}$ & $\begin{array}{c}\text { Total of Rejected } \\
\text { Claim }\end{array}$ & $\begin{array}{c}\text { Rejected } \\
\text { Warranty Value } \\
\text { (In Million rupiah) }\end{array}$ \\
\hline 13,110 & 38,313 & 2,930 & 8.420 \\
\hline
\end{tabular}

The late submission of warranty claims is another problem faced by the dealers of PT. XYZ in the warranty process. Warranty claims sent to PT. XYZ 28 days after the work started should be rejected automatically. During 2017, total rejected warranty claims due to the late submission are 33 with a value of 89 million rupiah. Indeed, in quantity and value, the rejected claims due to late submission problems are relatively small compared to administrative problems; however, PT. XYZ does not tolerate any late claims; therefore, the dealer should bear the cost of these claims [17].

TABLE IV. Number of Rejected Claims Due to the Late Submission

\begin{tabular}{|l|l|l|l|}
\hline $\begin{array}{c}\text { Total of Warranty } \\
\text { Claim }\end{array}$ & $\begin{array}{c}\text { Warranty Value } \\
\text { (In Million } \\
\text { rupiah) }\end{array}$ & $\begin{array}{c}\text { Total Warranty } \\
\text { Claim Submission } \\
\text { > 28 Days }\end{array}$ & $\begin{array}{c}\text { Rejected } \\
\text { Warranty Value } \\
\text { (In Million rupiah) }\end{array}$ \\
\hline 13,110 & 38,313 & 33 & 89 \\
\hline
\end{tabular}

In this thesis, the above issues were explored more deeply, in particular identifying the root of the problem, solving the problem, and avoiding future problems. In the end, the result of this thesis will hopefully create comprehensive settlements to be used as a reference for further internal control research.

This paper will attempt to address the following questions:

- Why do PT. XYZ networks maintain such a large balance on transit account warranty transactions?

- How can managers improve the warranty process and associated processes such as spare parts procurement of PT. XYZ. This will be reviewed by comparing Standard Operating Procedures (SOP) with actual implementation in the field.

A. The Aims of the Research

The aims of the Thesis/Research are as follows:

- To seek solutions on how to avoid the large balance of warranty transactions in the future by designing control over the warranty process.

- Designing SOP and control design for the warranty process in the dealer network of PT. XYZ and propose some improvements on the SOP in the management and control of the warranty transactions. 


\section{THEORETICAL REVIEW}

\section{A. Internal Control}

Internal control is a process that is implemented to provide rational certainty that the following control objectives can be achieved [13]:

- Securing of assets: to protect or detect unauthorized acquisition, use, and disposition.

- Maintain recording with sufficient detail in reporting company assets accurately.

- Provide accurate and reliable information.

- Prepare financial statements in accordance with established criteria.

- Promote and improve operational efficiency

- Encourage compliance in determining management policies.

- Comply with the applicable laws and regulations.

Internal control is an important process because it absorbs the operational activities of an organization and is an integrated part of management activities. Internal controls provide rational certainty, in which complete certainty is very difficult to achieve and very expensive. Additionally, internal control systems have inherent limitations, such as vulnerability to simple errors, wrong judgment and decision making, rejection of management, and collusion [13].

Developing an internal control system requires thorough understanding of the capabilities and risks of Information Technology (IT), as well as how to use IT in achieving management control objectives. Accountant and system developers assist management in achieving its control objectives by:

- Designing an effective control system that requires a proactive approach to eliminate system threats, and which can detect, correct, and fix threats when they appear.

- Simplify by developing controls in the system at the initial design phase rather than adding after the case happened [13].

- Internal control performs three important functions [13]:

- Preventive control: Prevent problems before they occur, for example, hiring qualified employees, segregating employee responsibilities, and controlling physical access to assets and information.

- Detective control: Knowing the problems that cannot be prevented, for example, tiered checks on calculations and preparing bank reconciliation reports as well as trial balance on a monthly basis.

- Corrective control: Identifying and correcting the problems, as well as correcting and fixing the things that can cause the problems. For example, backing up copies of documents, making correction to incorrect data entry, and resending transactions for subsequent processing. [13]:

Internal controls are usually divided into two categories

- General control: ensuring the organization's control environment is stable and well managed.

- Application control: Ensuring that the transaction is processed correctly. This relates to the accuracy, completeness, validity, and authorization of the data collected, inputted, processed, stored, and sent to other systems and reported.

Four levels of control to assist management using creativity and control in conflict management, namely [13]:

- Trust system: Describes how a company builds value, helps employees to understand the vision of management, communicates the core values of the company, and inspires companies to achieve those values.

- Limited systems: Help companies act ethically by setting limitation on employee behavior. Employees are not told exactly what to do. Instead, they are encouraged to creatively solve problems and meet consumer needs when fulfill minimum.

Implementing performance standards, avoiding forbidden activities, and avoiding actions that might damage reputations.

- Diagnostic control systems: measure, monitor and compare the company's actual progress with the budget and objectives of its performance. Feedback will help management to adjust and provide appropriate input and processes, so future results are closer to the final destination.

- Interactive control system: helps managers to focus more on their subordinate objectives on key strategic issues, and to be more involved in discussions. Interactive data systems are described and discussed at face-to-face meetings between superiors, subordinates, and other co-workers.

Unfortunately, not all organizations have an effective internal control system. For example, one report indicated that the Federal Bureau of Investigation (FBI) was disrupted by issues of vulnerability and security of IT infrastructure, some of which were indicated in the audit 13 years ago. Specific areas of concern are security standards, guidelines, and procedures; task separation; access control, including password management and its use; backup control; software recovery and development; and change control. Change control used to ensure that changes of system or product were implemented in structured and coordinated manner.

\section{B. Committee of Sponsoring Organization (COSO) Internal Control Model}

The Committee of Sponsoring Organization (COSO) members consist of The American Accounting Association, 
The American Institute of Certified Public Accountant, The Institute of Internal Auditors, The Institute of Management Accountants, and The Financial Executives Institute. In 1992, COSO issued the Internal Control-Integrated Framework (IC), which is widely accepted as an authority on the internal control system and incorporated in policies, laws, and regulations that are used to control business activities [13].

\section{COSO Enterprise Risk Management Framework}

To improve the risk management process, COSO developed a second control framework called Enterprise Risk Management-Integrated Framework (ERM). ERM is a process used by directors and managers to determine strategies, identify events that may affect a company, make assessments, and manage risks as well as provide reasonable assurance that the company can achieves its goals and objectives. The basic principles behind ERM are as follows [13]:

- Company is formed to create value for its owners.

- Management should decide how much uncertainty will be received at the moment of the value occurrence.

- Uncertainty leads to risk, allowing something negative to affect the company's ability to create or maintain value.

- Uncertainty results in opportunity, which allows that something positive affects the company's ability to create or maintain value.

- The ERM framework can manage uncertainty and also create and maintain value.

\section{Enterprise Management Framework Versus IC} Framework

The IC framework has been widely adopted as a way to evaluate internal control. However, it also tests control without looking at the objectives and risks of the business process and provides little context for evaluating results. Under the IC framework, it is very difficult to find out which control system is the most important, whether it is sufficient to handle risks, and whether important controls are even missing [13].

More comprehensive ERM frameworks would have a risk base instead of control basis approach. ERM adds three additional elements to the IC COSO framework: determine goals, identify events that may affect the company and develop responses to assess risks. Consequently, controls become flexible and relevant because they are connected to the organization's current goals. The ERM model also recognizes that these risks can be controlled, accepted, avoided, diversified, shared, or transferred [13].

\section{ReSEARCh MethoD}

\section{A. Types of Research}

This study used qualitative research methods. Qualitative data is data in the form of words (Sekaran, 2016). Examples of qualitative data are interviews, transcripts from focus group, answers to open questions, transcriptions of video recordings, accounts of experienced people on a product on the internet, news articles, and other similar activities. Qualitative data can come from a variety of primary and secondary sources, such as individuals, focus groups, company records published by governments, and the internet (Sekaran, 2016).

Furthermore, the research strategy approach in this research is the case study approach. In case studies, the focus is on collecting information about objects, events, or specific activities such as an organization or particular business unit. In case studies, the discussed case may be from individuals, groups, organizations, events, or situations that are of interest to the researcher. The idea behind a case study is one must examine real-life events from different angles and perspectives by using various data collection methods to get a clear picture (Sekaran, 2016).

\section{B. Source of Data}

The sources of data used in this study are primary and secondary data. Primary data sources in this study were obtained from direct observation either by doing direct observation of the dealers and related departments, observation of field evidence such as photographs or drawings, participant observation from those involved directly in the warranty process step by step and conducting interviews with the parties involved in the warranty process. For interviews, 10 respondents were selected; the aim was to dig deeper for information and find out the source of problems in the warranty process.

The secondary data sources in this study were obtained from data downloads taken from related information systems, company documents, SOPs, previous research results, and related information published through the internet.

\section{Data Collection Technique}

In this research, three types of data collection techniques were used: interviews, direct observation, and collection of documentations. The three types of data collection techniques are considered to be able to fulfill the data needs in this study. Data being used in this research were from 2013 until 2017.

\section{1) Interview}

Structured interview was the interview technique used in this research. This was selected so that respondents could directly provide information in accordance with the intended given question. This was done for the sake of interview time efficiency, considering all the selected respondents were fulltime employees; therefore, the interview session could not interfere with their work.

Prepared questions in structured interviews are openended questions, which are intended to allow respondents to provide the desired answers, and it is intended that respondents can provide comments with a wider scope (Sekaran, 2016). The selected respondents were those directly involved in the warranty process either from PT. 
$\mathrm{XYZ}$ or the dealers; 10 respondents total were interviewed. The selected respondents were those who work in the warranty department, accounting, spare parts warehouse staff, mechanics, and the IT Business Process Specialists. The selected respondents should have at least 1 year of experience in their respective fields so that their experience would be able to provide enough information regarding the warranty process in each company.

The questions in the interview were designed to acquire as much information as possible about the warranty process to get the full picture of the root of the problems occurring in the warranty process. The questions for the interview session were as follows:

- Please explain as a whole how the warranty process in your company.

- What role do you perform in the warranty process in your department?

- Does your company already have a warranty SOP?

- Do you think there are any overlooked aspects of the process listed in the SOP? If so, which part should be fixed?

\section{2) Direct Observation}

Observations focus on planning, recording, analysis, and interpretation of behaviors, actions, or events (Sekaran, 2016). This research used a natural setting (uncontrolled) method, meaning the observed environment was occurred in an actual situation or naturally. Therefore, the information of the existing problems in the warranty process could be seen directly. The second type of observations were made by engaging directly or participating in the process of daily warranty review by the company or dealer. Conducted observations have been structured to determine what processes and physical evidence should be observed. Observations were also conducted openly, and respondents were told beforehand that they were the objects of the research.

The following factors were observed.

- Personnel involved in the process

- Steps of the warranty process from each department

- Warehouse storage of spare parts

- Warehouse storage of spare parts claimed in warranties

e. Destruction of warranty-claimed goods

3) Document Collection

The required documents in this study are as follows:

- SOP of the warranty process, if any. The SOP documents were checked and matched against findings at the time of the observation to review whether the dealer had a guide present for daily warranty issues.
- Proof of warranty claim and evidence of claim response from Original Equipment Manufacturer (OEM in Indonesia ATPM - Agen Tunggal Pemegang Merk): At the first stage of the warranty process, the dealer make a warranty claim to the ATPM (in this case PT. XYZ), then PT. XYZ accepts or denies the claim. The proof of these claims were checked by bookkeepers' recordings of the warranty transaction for each dealer.

- Proof of warranty transactions bookkeeping: Every warranty transaction bookkeeping instance was checked and matched against the claim proof. Is every claim that received a response from PT. XYZ recorded on time, in accordance with the number of claims, and for the correct accounts?

- Evidence of destroying/delivery of warranty-claimed goods: After the dealer receives the claim, PT. XYZ as ATPM should perform the destruction of claimed spare parts then also check whether the mentioned spare parts have been destroyed and whether the documents and controls are fit. Prior to destruction, the dealer usually places spare parts in a temporary warehouse, the document of the list of spare parts that have not been destroyed were also checked.

- Chart of Account: Chart of Account documents are required to find out which accounts are used in recording of warranty transactions.

- Financial report of each dealer: Dealer financial report are useful to find out the size of warranty transactions from time to time as well as to find out the size of the impact if there was an error recording the warranty process in the financial performance of the concerned dealer.

The warranty process is usually handled by warranty staff at each dealer who is responsible to the Workshop Administrator, whose position is in the same level as the Supervisor. The Workshop Administrator is responsible to the Workshop Manager who has full responsibility for the operation of the workshop as a whole.

\section{RESUlt AND DiscUSSION}

\section{A. Spare Parts Purchasing Process and Stock Input}

Regarding the spare parts purchasing process and stock input, the responses suggested that the process of receiving spare parts stock encouraged accounting record inaccuracies at the time of Good Receive - Invoice Register (GR/IR) verification. This certainly affected the accuracy of dealers' financial statements, which ultimately could lead to decisionmaking errors for policymakers both from PT. XYZ and the dealers. Most problems involved the verification processinvoice delivery occurs after the delivery of goods, which is a complicated process due to the difference in time between delivery of goods and invoice delivery. The process of accounting recognition was done as follows:

- At the of receipt of goods

- At the time of receipt of invoice 
- Verification when the problem at the time of verification occurs due to:

-an unknown gap.

-account users not getting a goods' status update.

\section{B. Warranty Claim Creation}

The summarized results of this research suggest claim data should be entered carefully and correctly so that claims will not be rejected by PT. XYZ. Taken from the warranty SOP guide, some steps to improve warranty processing include:

- Registering the warranty job and inputting:

-customer data: customer name and customer code

-vehicle data: vehicle number, registration date, registration number, odometer/vehicle mileage at next service, repair date, franchise code, vehicle type (passenger or commercial vehicle)

-dealer data: dealer number/code, service advisor code

- Inserting warranty job information: Damage code is a code of "damage" that can be claimed by the ATPM, issued by the manufacturer, and always updated when every new model is launched.

- Release warranty claim: Prior to completing a release claim, a "plausibility process" was performed. "Plausibility process" is to conduct a check/match between job data in work-in-progress (WIP) documents to match with inputted damage code. If the check result is correct, the claim can be released immediately.

\section{Claim Process and Warranty Claim Delivery}

The problem analysis in this process were as follows:

- Late submission of warranty claim, where the claim should be made within 28 working days maximum after work started. Late submission could be due to the lack of oversight so that the claim delivery process was missed or the workshop unit did not do WIP closing on the already-assigned warranty work.

- Rejected claims were not reclaimed. This can occur because the warranty operators did not read the existing message on the PT. XYZ claim reply carefully. Communication in the warranty process system uses English, presenting a challenge to many warranty operators.

- No transfer knowledge to new employees, as there was no available complete warranty guide in the dealership.

\section{Warranty Claim Responses}

Problems encountered in the claim acceptance process can be summarized as follows:

- Upon receiving a claim response, no information was submitted to the accounting department.
- The accounting department did not know the process as a whole.

- EVA gave R20 files to DMS that contained information about how much money have to pay, post-to-account process should be done but not be done.

- There was a difference in the payment time where claims had been received but money had not been transferred from PT. XYZ.

\section{E. Analysis of Accounting Journal in Warranty Process}

After conducting an interview, problems in the warranty process that resulted in inaccuracies of journal results in accounting were analyzed one by one as follows:

1) Recognition Journal of Spare Parts Purchasing and Stock Input

The results of the study found that most dealers did not perform the verification process correctly. The accounting journal for the recognition of spare parts stock is as follows:

- Goods receive Process:

$$
\begin{aligned}
& \text { Dr. Stock } \\
& \text { Cr. Account transitory / Good Receive }
\end{aligned}
$$

- Invoice register Process:

Dr. Account transitory / Invoice not receive

Cr. Account Payable

- Verification Process:

\section{Dr. Account transitory / Good Receive \\ Cr. Account transitory / Invoice not receive}

- Verification process if there is a gap in journal is as follows:

\section{Dr. Account transitory / Good Receive \\ Dr. Courier expense / Stamp duty expense}

Cr. Account transitory / Invoice not receive

Since most dealers did not verify or fail to verify properly, as the user did not know what to do to resolve the gap (if it appears) in the final result of the verification, the end result in the dealer financial statements is that Account transitory (good receive and invoice not receive) that was not eliminated (not close)

- Account payable to PT. XYZ (as a major supplier of spare parts) was high or unpaid

- Courier, and stamp duty costs were too small because they were never recognized.

2) Recognition Journal of Work Registration When Customer Arrives

At the time of work registration processing, the service advisor inputs the data of the vehicle and if there is any damage on the spare parts, and still within the warranty period, the service advisor gave the warranty status on the transaction. After that, the service advisor inserted any spare parts needed in car work. Furthermore, the mechanic then 
take the required spare parts at the spare parts warehouse. When the spare parts come out from the warehouse, the journal formed automatically in the DMS system as follows:

\section{Dr. Work in Progress}

\section{Cr. Stock Genuine}

In this process, since it is done automatically in the system, no problems arose. Because based on the result of the interview, this process was always done by all users.

3) Work Closing Recognition Journal and Warranty Claim Submission to PT. XYZ

When the work is done, the service advisor then does the "closing," by doing print an invoice. And because of the warranty work, the invoice addressed / set to the warranty customer account i.e., PT. XYZ. At the time of the invoice is printed, the journal posted automatically as follows:

\section{Dr. Warranty Suspense \\ Cr. Claim to supplier \\ Dr. Warranty Suspense 1 \\ Cr. Work in progress}

From the results of the analysis for this process, it was found that almost all dealers did it. Therefore, from the side of accounting recognition journal, no problem was found.

4) Recognition Journal on the Acceptance of Claim Answers from $P T$. XYZ

At the time of acceptance of claim answers, there are several possibilities, such as:

- Whole claims are accepted

- Only partial claim is accepted

- Claim is rejected overall

If the first alternative happens, then the possibility of the journal will be:

Dr. Nominal Ledger Suspension

Cr. Warranty Suspense

If only partial claim is accepted (second alternative), the journal will be:

\section{Dr. NL Suspense \\ Dr. Claim to supplier}

Cr. Warranty suspense

If the claim is rejected overall, the journal will be:

Dr. Claim to supplier

Cr. Warranty Suspense

Dr. Warranty Expense

Cr. Warranty Suspense 1

Some dealers did not process post-to-account when they received a warranty claim response. Post-to-account process generates accounting journals as mentioned above.
Transitory account that still have a balance as a result from a non-executable process were as follows:

- The Warranty Suspense value was too big on the debit side.

- Claim to supplier was too big on the credit side.

5) Recognition Journal on Delivery of Warranty Claim Invoice

After receiving the claim response from PT. XYZ, the subsequent thing that should be done by the dealer is to send the warranty claim invoice to PT. XYZ. Here, the warranty invoice is recognized as spare parts sales and services. Billing were done in DMS system on module generate and print documents. When executing an invoice, the system posts automatically as follows:

\section{Dr. A/R Warranty \\ Cr. Sales Parts \\ Cr. Sales Service \\ Cr. VAT}

At this stage, there were some dealers who neglected to or even not did not at all. Consequently, warranty receivables were not posted on the system. Dealers preferred to record these warranty receivables on their internal systems, and the quality of data at the required DMS systems was not maintained.

6) Manual Journal to Close Warranty Transactions

The last step to close the process of warranty in accounting, besides doing manual journal on some accounts that have been posted is also doing the recognition of the cost of goods. The journal is performed by the accounting department based on several reports as follows:

- General Ledger Report: In this report accounting information on how much the value should be journaled to close the account of Claim to supplier can be obtained, NL Suspense dan Warranty Suspense 1

- Warranty report: In the warranty report, the accounting department obtain the value of the cost of sales parts.

After obtaining the basic calculations for the journal, accounting department then do the journal manually are as follows:

Dr. Claim to supplier

\section{Cr. NL Suspense \\ Dr. Cost of sales Parts}

\section{Cr. Warranty Suspense 1}

For manual journals, many dealers also did not do the recognition, and based on the results of the interview this was because the dealer was not aware that the manual journal should be done. If the manual journal was not done, the cost of sales parts were not posted, thus, causing less recognition of costs, and some transitory accounts such as 
claim to supplier NL suspense and warranty suspense 1 is bigger on the balance sheet side.

\section{CONCLUSION AND RECOMMENDATION}

\section{A. Conclusion}

Based on the results of the research, there are still many problems in the warranty process of the PT. XYZ network dealerships. The mismatch between dealer invoices and final financial statements can certainly lead to poor decision making. The following problems occur:

- Since warranty is a liability and is borne by the producer, the PT. XYZ dealer is not required to perform warranty provisions unless the dealer provides additional warranty on the product.

- Warranty provisions are not recognized by the dealer, as there is a possibility that the consumer buys a vehicle and claims the warranty at a different dealer; therefore, the recognition and actual repairs are not balanced.

- Phase of purchasing process of spare parts and stock input of the stock parts recognition: There is a gap during the verification process GR-IR, but the dealer does not know how to treat the gap and accounting users do not get information or reports on the input of goods on a regular basis

- Step to make warranty claims: Incorrect input of damage codes, excess in claimedworking hours from mechanics, work that should not have been claimed but is listed as complete, lack of dealer info on updated damage codes, etc.

- Claiming process and warranty delivery: Late submission of claim warranty maximum 28 working days after open WIP/work started, the rejected claim is not reclaimed, use of English language in SOP, and no knowledge transfer to new employees.

- The process of receiving the response of the warranty: No information to the accounting department, the accounting department does not know the overall process, EVA sent the file to the DMS that informs how many claims will be paid, then have to make post-to-account process but not be done.

- Regarding the journal analysis, it is revealed that users do not perform some steps in the warranty accounting journal process; they do not do manual journals in accordance with the instruction. This is due to the user not knowing the process.

- There is no indication or report that some warranty claims are not up to the accounting department.

The following responses address the previous problems:

- Information on account for recognition of the gap on the verification value should be written in the guide book. Users should be trained on how to post the gap in the system.

- Spare parts administrators should provide periodic reports to the accounting department, i.e., after completing the stock input (Goods Receive).

- User warranty representative should check updates to the warranty system damage code (intra/EVA) every day.

- Before inputting warranty work into the system, warranty operators should check whether there is a working hours update in the warranty system (intra/EVA).

- Before performing warranty work, warranty operators must perform periodic checks to the warranty system (intra/EVA).

- In addition to checking warranty systems periodically (intra/EVA), PT. XYZ should also inform all dealers every time there is an update.

- Warranty operators are required to refresh the data in the system periodically to find out whether there is any next warranty claim process to be done.

- The head of the workshop unit should control work by downloading a WIP report every day, including reports, work completed, unfinished work, outstanding work, and assigned-to-warranty work, etc.

- Prior to the advanced process, warranty operators should be required to read the message contained in the claim reply.

- Since all communication in the system is in English, the dealer should recruit warranty operators who are at least able to speak passive English.

- A comprehensive warranty process guide should be prepared in the Indonesian language, so that, when there is a change of personnel, the new warranty operator will be able to do the work according to the guidelines.

- The head of the workshop unit should provide regular and active reports to the accounting department so that the accounting department can quickly find out which claims that have to be processed further.

- Documenting of the SOP/warranty process guidebook, and every employee involved in the process should be retrained at least twice a year.

- The head of the workshop unit should ensure that there is no delay in reporting from warranty operators. If possible, accounting users can access the warranty system, especially for warranty reports; therefore, it does not always depend on reports from the workshop/warranty department.

\section{B. Recommendations}

Recommendations for further research are as follows: 
- Broaden the scope of research; if there is a dealer providing warranty details to a customer, what is the transaction process and analysis.

- Comparing the treatment of warranty transactions from dealers of PT. XYZ with dealers of other brands.

- Studying whether the dealer warranty transaction is profitable for the dealer.

- Studying whether there is an increase in customer satisfaction and/or customer loyalty over the application of warranty policies.

- Studying whether a producer applying warranty projects more responsibility or increased customer satisfaction and loyalty.

- Arranging the standard of warranty audit procedures to implement a more efficient warranty process.

\section{REFERENCES}

[1] Benjamin, Catherine, Kevin Cherrstrom, Tony de Bell, Michael Dion, Angela Fergason, Jogn Gochoco, Sebastian Heintges, Samying Huie, Valerie Wieman, and Katie Woods (2017). Revenue from Contracts with Customer. PricewaterhouseCoopers.

[2] Center for Automotive Research. (2005). The Warranty Process Flow Within the Automotive Industry: An Investigation of Automotive Warranty Process and Issues. Center for Automotive Research.

[3] Consumer Protection Law Republic of Indonesia No. 8 Year 1999 (1999).
[4] Dealer Dashboard Report PT. XYZ periode 2013 - 2017

[5] Dealer Financial Report PT. XYZ period 2013 - 2017

[6] Fiscal Policy Agency (2017). 2016 Economic, Financial \& Fisca Review: Indonesian Economic Turning Point. Ministry of Finance Republic of Indonesia.

[7] Gaikindo (2017). Wholesales, Retail Sales, Production, Export, Import Report by Category 2012-2017. The Association of Indonesia Automotive Industry.

[8] Iskandar, Bermawi P. (2010). Product Guarantee Management and Its Development in Indonesia. Faculty of Industrial Technology. Bandung Institute of Technology. Bandung.

[9] Juniarti, Jeannette. (2012). Product Liability In The Automotive Industry. Postgraduate Law Program. Faculty of Law University of Indonesia. Jakarta.

[10] Kieso, Donald E., Weygandt, Jerry J., Warfield, \& Terry D. (2011). Intermediate Accounting (IFRS ed.). John Wiley \& Sons.

[11] Lutfi, Mohamad. (2008). Analysis of Aftersales Service Customer Satisfaction Index of Hitachi Heavy Equipment. Management and Business Postgaduate Program. Bogor Agriculture Institute. Bogor.

[12] Mitsubishi Fuso Press Release (2016). Press Release 2016. Krama Yudha Tiga Berlian. Jakarta.

[13] Marshal, Romney B., Steinbart, \& Paul J., (2012). Accounting Information System (12th ed.). Pearson.

[14] Santosa, Elisabeth Cintya. (2004). Role of Warranty To Increase Customer Satisfaction In Service Companies. Marantha Management Journal. Jakarta.

[15] Vollmann, Thomas E., Berry, William L., Whybark, D. Clay, and Jacobs, Robert F. (2005). Manufacturing Planning and Control Systems. Boston: McGraw-Hill.

[16] Warranty Business Process and Guideline PT. XYZ

[17] Warranty DealerTransaction Report PT. XYZ period 2013 - 2017 